\title{
First record of the fossil dragonfly family Eumorbaeschnidae from the Upper Jurassic of Poland
}

Günter Bechly and Adrian Kin

Acta Palaeontologica Polonica 58 (1), 2013: 121-124 doi: http://dx.doi.org/10.4202/app.2011.0194

The fossil dragonfly Eumorbaeschna adriankini sp. nov. is decribed as first fossil insect from the Upper Jurassic of

Central Poland (Owadów-Brzezinki quarry, Tomaszów Mazowiecki area), and as first record of the family Eumorbaeschnidae (Odonata, Anisoptera, Aeshnoptera) outside the Solnhofen lithographic limestone.

Günter Bechly [guenter.bechly@smns-bw.de], Staatliches Museum für Naturkunde Stuttgart, Rosenstein 1, 70191 Stuttgart, Germany. Adrian Kin passed away on June 26th, 2012.

This is an open-access article distributed under the terms of the Creative Commons Attribution License (for details please see creativecommons.org), which permits unrestricted use, distribution, and reproduction in any medium, provided the original author and source are credited.

FaF Full text $(263.5 \mathrm{kB})$ 